\title{
Calvin and Luther - Their Personal and Theological Relationship
}

\author{
WH Neuser
}

The theologies of Luther and Calvin have often been compared with each other. I would like to take the scholarly discussion about their theological relationship a little further by describing in the second part of my lecture the fundamental difference in the religious situations which confronted Calvin in Geneva and Luther in Wittenberg, and in the third part to try and show the basic unity which existed between the two reformers. Modern research has revealed only a little information concerning the personal relationship between the two greatest reformers. Nevertheless, in this first section I want to investigate their personal relationship because the hitherto familiar picture can be augmented from new sources.

Calvin and Luther never met. Melanchthon was loathe to surrender the only letter which Calvin wrote to Luther in 1945, because the quarrel between Wittenberg and Zürich over the Lord's Supper threatened to break out again. The only actual recorded contact between the two men was when Bucer was asked by Luther on the 14th October 1539 to convey his greetings to Calvin. All that remains is to record only indirect references to one other. On Luther's part it is known hat he spoke highly of two works only, Calvin's "Brief tractate on the Lord's Supper" of 1541 and his "Fervent exhortation to the Emperor Charles V" of $\mathbf{1 5 4 5}^{\mathbf{1}}$. On Calvin's part his early dependence on Luther's classification of the catechism may be mentioned which is verified in the first edition of the Institutes (1536); his authorship of the famous rector's address at Paris on November 1st 1533 which makes use of Luther's church sermons ${ }^{2}$ (Kirchenpostille) has not been ascertained with certainty. One might add Calvin's remarks about Luther in letters. They usually refer to the dispute over the Lord's Supper and are marked by a deep regard for Luther even when he is forced to criticise Luther's doctrine of the Lord's Supper and his pugnacity. These are the most important reciprocal references. However, in more recent time a letter has come to light from Martin Bucer to Veit Dietrich in Nuremburg dating from 19 November $1539^{3}$, which throws new light on the relationship between the two reformers 4 . 


\section{LUTHER'S DEFENCE OF CALVIN AGAINST THE CHARGES OF THE NUREMBERG THEOLOGIANS IN THE YEAR 1539}

Up to the appearance of that letter only three documents were known which described relations between Luther and Calvin in 1539. They did not appear to make much sense because the occasion for Luther's remarks about Calvin was not known and consequently the importance of Luther's opinion could not be evaluated. No information can be obtained from the three documents that the Lutheran theologians in Nuremberg took part and that they raised with Luther objections to Calvin's doctrine of the Lord's Supper. This fact only comes to light in the letter of Martin Bucer. Our task is to comment on the four pieces of source material and to examine their correlation.

The first document is the letter already mentioned of Luther to Bucer on the 14th of October 1539, in which he wrote at the close: "Give my greetings also to John Sturm and John Calvin, whose books I have read with great enjoyment" ${ }^{\prime \prime 5}$. The following sentence shows that Luther has read the writings of both men against Cardinal Sadolet and commended them. The rector of the gymnasium in Strassburg, Sturm, had published "Epistolae de dissidiis religionis", and Calvin published his famous "Responsio ad Sadoletum". It is noteworthy that Luther had read what was probably Calvin's most impressive writing, his fiery retaliation against the Church of Rome. Over the past centuries in Germany numerous translations of this essay have appeared ${ }^{6}$.

The second document is the oral report of the Strassburg printer Mylius, which he brought with him from Wittenberg together with Luther's letter. Calvin handed the report on to Farel in Neuchatel on the 20th of November, 1539: "Philipp (Melanchthon) wrote: 'Luther and Bugenhagen send greetings to Calvin and Sturm. Calvin is being favourably received'. Furthermore Melanchthon reported by messenger that to incite Luther the latter was shown how severely he and his followers were criticised by me (Calvin). Luther looked more closely at the particular passage (in the book) and remarked that without doubt it contained an allusion to him. Then he said: 'I hope that one day Calvin will think better of us. It is only fair that for once we accept something from this great soul."' Calvin adds: "I am overcome. And so I have written something which will give him adequate satisfaction (satisfactio). It will be put into the preface to the commentary on the epistle to the Romans"7. The impression which Calvin's letter to Sadolet made on Luther weighed more with him than Calvin's criticism of the Lutheran doctrine of the Lord's Supper. Luther was not offended by the criticism. The question as to who accused Calvin to Luther remains open in Calvin's account. No 
indication whatsoever is given. The book whose doctrine of the Lord's Supper is directed against Luther might be the letter of Sadolet ${ }^{8}$, but probably it is the newly published Institutes of $1539^{9}$. The "satisfactio" which Calvin wants to prefix to his Romans commentary is clearly identifiable.

This is the third document which we already knew about. We have the document in Calvin's own handwriting. However he did not fulfil his intention to publish it in the preface to his Romans commentary (1540). It is indicative of the difficult situation at that time that Melanchthon, who met Bucer towards the end of the year 1539 , advised against publication ${ }^{10}$. Calvin published only his didactic middle section which was inserted into the chapter on the Lord's Supper in the Institutes of 1543. It constitutes paragraph 11 of Book IV, chapter 17, in the final edition.

The section which is not printed in the Institutes is the really interesting one. In it Calvin recalls: "when I was told recently that certain people ... had taken offence at the recently published edition of my Institutes, I was not a little affected by it. They had taken offence because it was supposed that I intended to kindle anew the disputes which had broken out at that time concerning the presence of the body and blood of Christ in the Lord's Supper, and which had quietened down again to a certain extent, and (it was supposed that I intended) indirectly to reprimand the faithful servants of the Lord as though they taught a local presence in the Lord's Supper which is unworthy of Christ." Who the "certain people" (quidam) were is not specified here either. They obviously belonged to "the faithful servants of the Lord" who had become suspicious of a far too literal understanding of the real presence, as they understand it. This could refer only to Lutheran theologians, who complained about Calvin. Calvin's presentation indicates that two reproaches were levelled by these people against him or against the Institutes of 1539: renewal of the Lord's Supper dispute and hidden attacks against the local presence of the body and blood of Christ in the Lord's Supper. Calvin looks further into both accusations.

First he reiterates his regret that offence was taken, particularly at his representation of Christ's presence in the Lord's Supper. Altercation of any kind was far from his mind and this applied in particular to the renewal of the dispute over the Lord's Supper. He hoped, however, to be able to appease them and provide adequate satisfaction (aequa satisfactio). He certainly did not want to disturb the Concord of Wittenberg (1536); he had willingly accepted it. Now follow those dogmatic passages which were incorporated into the Institutes. One can recognise from the concepts ${ }^{12}$ that paragraph 11 of Institutes IV, 17 represents a comment on the Concord of Wittenberg. In his expositions Calvin emphasizes the word of promise 
(promissio) and, without mentioning names, keeps clear of Zwingli's doctrine. However, here we do not wish to consider further Calvin's attitude to the Concord of Wittenberg and to Zwingli.

More important for our subject is that Calvin in the final part of his "satisfactio" which likewise was not published, names the passages which his critics has objected to in the Institutes of 1539 . There are two of them. The first is: the Lord's Supper "is the bread which is consecrated by the body of Christ, and the wine which is consecrated by the blood of Christ" ${ }^{\prime 13}$. Calvin adds the explanation that this mode of expression originated with the church father Chrysostom and is a mystical eulogy (mystica eulogia). Calvin did not insert the offending passage to the Institutes of 1543 nor to the later editions. The deletion was effected not only out of consideration for the Lutheran theologians but also owes something to his own aversion to imprecise formulations.

Calvin did not remove the second contentious passage from the Institutes. It occurs in the next paragraph, IV, 17, 12, and reads: "And first we must not dream (of such a presence of Chirst in the sacrament) as the clumsy Sophists in the (scholastic) schools have fashioned, as if the body of Christ, by a local presence, were put there to be touched by the hands, to be chewed by the teeth, and to be swallowed by the mouth"14. In the "satisfactio" he defends the passage written by him as follows: "Indeed, because some of the people from the group with whom we are now reconciled think that they were abused by me, I would like them to remember in this connection at what point in time I first wrote the passage. My pen was directed against those who saw almost nothing in the sacrament but the crude presence of Christ which could be apprehended by bodily sensation and almost be touched by the hands." This sentence already comes from the Institutes of 1536. By drawing attention to the historical context of the passage Calvin makes it clear that it was directed against the disciples of Rome. He does not, however, mention a name to make it clear whom he is addressing. The observer gets the impression that Calvin did not wish to demarcate the circle of people, against which the passage was directed. But in 1536 he could not have known who his actual critics were. Only in the edition of 1559 does he name the authors of the false doctrine. They were the impostors of the Roman court (Romanae curiae artifices). The form of recantation which Pope Nicholas II dictated to Berengarius of Tours is mentioned as the source ${ }^{15}$. We conclude that the content of both the contested passages from the Institutes permits no clear conclusion as regards the theologians in dispute.

However, the final part of Calvin's "satisfactio" is more helpful. I reiterate the first half sentence: "Indeed, some from the group of people, with whom we are reconciled, think ...". The "certain 
people" (quidam) who caused Calvin to write his "Satisfactio" were only some of the Lutheran theologians (nonnulli ex iis), with whom the Strassburgers composed the Concord of Wittenberg. Contrary to the opinion of some scholars, Luther and the rest of the Wittenberg theologians did not have to join in the criticism of Calvin at all.

The fourth document, the letter of Martin Bucer to Veit Dietrich on the 19th of November 1539 proves that the Nuremberg theologians Osiander, Linck and Dietrich were the critics. The letter of Bucer and Calvin's "satisfactio" not only complement each other perfectly, but the motive and object are clearly identical. Thus Bucer writes about "Calvin's inopportune treatise": "I assure you that Calvin approves of our Concord and the way we talk about the Lord's Supper. This fact reassures us in regard to his book which he has published here. He acknowledges the real presence of the body of Christ in the Lord's Supper"17. Bucer then begins to speak of Zwingli's followers: "But he seeks to satisfy those who still accuse us - decided by what clamour I know not - of either mixing Christ in a despicable manner with the elements or enclosing him in outline locally in the elements. Therefore he has turned away from the customary manner of speaking about what is sacred so that he does not appear as someone who knows something of this particular subject." Bucer points to the situation in France. "On this account Calvin takes the French people too much into consideration as he also discusses the Lord's Supper in his Institutes rather too broadly and not in accordance with our own approach to the problem, in order to lead back his followers to the right interpretation; in his 'Responsia ad Sadoletum' he inserts something similar"18. Finally Bucer cites Luther's authorization: "In his forebearance towards foreign churhes Luther excuses Calvin's way of speaking and ordered that he should be greeted cordially"19.

With this the circle closes, because Bucer refers distinctly to Luther's letter of the 4th October and to the report of Mylius on Luther's amity towards Calvin. There can be no doubt that the four documents mentioned belong together. Indeed, Bucer justifies Calvin's method of teaching as due to his duty to maintain a dialogue with the French-speaking followers of $Z$ wingli. This applies above all to André Zébédée, pastor in Orbe ${ }^{20}$. On the other hand, Calvin himself declares that he had written the second contested passage against the disciples of Rome. The result is the same. In the exposition of the Wittenberg Concord he does not conceade to the theologians of Nuremburg any more than his doctrine of the Lord's Supper allows. In the question of the local presence of Christ in the Lord's Supper he lets some pointed comments against the Nuremberg theologians remain. Compared to him Bucer is extremely timid. He also sticks to the truth. But the way in which, in the same letter to Dietrich, he condemns the newly published utterances on the Lord's 
Supper by Bullinger, reveals the importance Bucer attached to Church politics.

Luther's behaviour leaves the strongest impression. He is willing to conserve the Wittenberg Concord and with it amity over the Lord's Supper. His position was difficult, because the Nuremberg theologians advocated at that time a quite rigid understading of the local presence of Christ in the Lord's Supper. In the year 1538 a discussion by letter took place between Veit Dietrich and Melanchthon in which the Nuremberg theologian advocated consubstantiation and the inclusion of the body of Christ in the bread and transferred the unity of the divine and human natures of Christ to the unity of the bread and the body of Christ. Melanchthon has disagreed vigorously ${ }^{21}$. The question must remain unanswered as to what extent the theologians of Nuremberg could find justification for their viewpoint on the basis of Luther's utterances in the Lord's Supper dispute. The accusation of the people of Nuremberg that the Concord on the Lord's Supper was broken by the Institutes of Calvin was surely of importance to Luther, too. The Mylius report from Wittenberg states explicitly that Luther knew that Calvin's utterances were directed against him. Moreover, Luther found that Calvins doctrin of the Lord's Supper understood only a spiritual presence and partaking of the body and blood of Christ. The way in which Calvin emphasised communion with Christ in faith and how this is linked with the Lord's Supper may have impressed Luther. In Marburg in 1529 Luther had not renounced the physical presence of Christ in the Lord's Supper. However in the 15th article of Marburg the spiritual strengthening is designated as "particularly necessary for every Christian". One can say that Luther maintains against Calvin that his strengthening is the main point ("particularly"). By interceding for Calvin he prevented a fresh outbreak of the Lord's Supper dispute. Also he recognised, or at least had some idea of, the significance of this "great soul".

\section{THE CONFLICT AGAINST NOMIANISM AND ANTINOMIANISM - THE DIFFERENT WORLDS OF CALVIN AND LUTHER}

It is not an improper generalization to call Luther the theologian of justification and Calvin the theologian of sanctification, because Luther always strove to maintain the purity of his discovery of the sinner's justification, and Calvin's theology had its centre in the believer's santification. It hardly needs mentioning that these statements refer to the different centres of gravity in the theologies of both reformers. Luther had also preached sanctification, of course, 
and Calvin's doctrine is based on the justification of the ungodly.

These differences are, however, more than simply different centres of graviy in their thinking. They are also more than merely criteria of the first and second generations of theologians of the reformation. While Luther says that the Christian is always sinner and justified at the same time, Calvin emphasised progress in the faith. Luther's formula "Simul iustus, simul peccator" or "partim iustus, partim peccator" stands in opposition to Calvin's formula of "continuus profectus" or "quotidianus progressuss"22. Karl Barth's verdict on Luther's doctrine of good fruits is surely unjus ${ }^{23}$ when he asserts it resembles the spring procession at Echternach in which the participants take one step forward and two steps back ${ }^{24}$. Luther did have misgivings about good works ${ }^{25}$ and feared a renewed lapse into a trust in one's own works and thus into justification by works. The Wittenberg debate of 1 June 1537 demonstrated that Luther denied the necessity of good works ${ }^{26}$. On the other hand, Calvin tirelessly emphasises the growth of obedience in faith because the Spirit of God is then seen to be effective. Whereas Luther depicts faith as a wavy line, which rises and falls, Calvin plots a line which rises very gradually and gently. Certainly he recognises backsliding and stagnation in faith. What dominates is progress in faith and not backsliding.

The late Reformed theologian Otto Weber, Professor of Dogmatics in Göttingen, detects a historical reason for the difference between Calvin and Luther when he comments: "A certain 'narrowing down" in the association of good works with justifiation "in the German Reformation may be explained by the fact that on the whole it had legalistic opponents. The western reformation, on the contrary, dealt mostly with libertine opponents who, however, did not elecit any declarations which were fundamentaly different in content from it but modified its mode of expression considerably in view of the German reformation"27. This interpretation is particularly applicable to Luther and Calvin. Melanchthon and Zwingli think primarily along the lines of Erasmian humanism which goes back to the ancient philosophers and establishes the ethic therefrom. They associate the sanctification of Paul with the ethics of humanism. They do not object, for example, to the epistle of James. In this they agreed with Calvin. What is concealed behind the concepts of "legalistic and "libertine" with regard to Luther and Calvin?

Under legalism one understands a legal piety which tries to evade the wrath of God through good works - albeit with the "help" of grace. Christ is for them the awesome judge, not the essence of the love of God. This is the picture which presents itself to Luther in Saxony as heir to the medieval church. It is not therefore incumbent on him to lay emphasis on the commandments of God in his congre- 
gations. The people knew that they were required to keep them. It was his task to explain to the congregation that sin was not primarily breaking commandments but disbelief which spurns the mercy of God. Faith is based on the divine forgiveness of sins, not on good works. It was always Luther's concern that the good works of faith were taken to be meritorious and understood as justification by works. Therefore legalism is his adversary ${ }^{28}$. J Bohatec has described vividly Calvin's "libertine opponents" in his book Budé and Calvin. Especially in the pamphlet entitled "The Apology of John Calvin to the Nicodemites" (1544) Calvin contends with those humanists at the French court who deride the ten commandments and glorify the "ethics" of pleasure, the life of love and adultery. F Wendel thinks that these were only isolated remarks or these humanistic circles would have soon returned to the Roman Church ${ }^{29}$. But $\mathrm{O}$ Weber is right when he says: "The western world of that time was already largely autonomously structured: (christian) preaching often appeared as something strange to it, and consequently the nature of law as address took on a much more concrete form ... He (Calvi), unlike Luther, is not primarily in dispute with legalism, ... but with an accomplished antinomianism, an ethical autonomy of thought, which could take the form of strictness as well as libertinism" ${ }^{\mathbf{3 0}}$. Thus because Calvin could no longer presuppose in the western world the knowledge of the law as divine demand he had to stand up to the antinominianism of his libertine opponents ${ }^{31}$. Weber concludes: Calvin "is forced out of circumstance to lay stronger emphasis on the address-nature of the law than Luther did"32. The different spritual and religious situation in the East and West is the reason for the distinct positions of Luther and Calvin with regard to the law. On the basis of the reasons just mentioned Calvin develops the doctrine of the third use of the law. This doctrine sets forth how God's law leads the believer to sanctification. It is found in the Institutes II, 7, 12-17 and need not be discussed here. It is important that Calvin terms tertius usus legis, the chief use of the law (usus praecipuus) ${ }^{33}$. As is well known, for Luther the most important task and actual purpose of the law is the exposure of sins. As we established at the beginning, it is the result of differing attitudes to justification and sanctification. It is obvious that Calvin and Luther are concerned not only with doctrinal distinctions but also with different alignments within the entire theology.

Nevertheless, their theologies are not totally opposite. It has already been mentioned that justification is not absent from Calvin nor sanctification from Luther. There was no dispute between them over these doctrines. However, Calvin's doctrine is the more relevant today. He experienced already in the western world the beginnings of secularization and the awareness of human autonomy 
which surrounds us today. The question then is whether the law of God must be preached today also in Calvin's sense as personal address and challenge to mankind.

\section{THE FUNDAMENTAL UNITY OF BOTH REFORMERS IN THE THEOLOGY OF THE WORD}

The concept of the "theology of the Word" has been familiar for some time now in evangelical dogmatics ${ }^{34}$. It has acquired special importance since the publication of E Bizer's book Fides ex auditu. Eine Untersuchung über die Entdeckung der Gerechtigkeit Gottes durch Martin Luther (1958, 1st edition). It was E Bizer who first drew attention to the fact that the rediscovery of the means of grace was a decisive factor in the Reformation doctrine of righteousness by faith. Luther had recognised since 1518 that faith came from preaching and depended on the Word of God. Luther's new programme is rightly called a "theology of the Word". For the grace it proclaims distinguishes his theology from medieval church doctrine; the proclamation of the gracious purpose of God determines his theology.

In 1964 Bizer examined the new understanding of grace and word of God in Melanchthons's thought and calls his doctrine of the

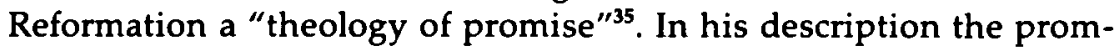
ise (promissio) of divine grace to mankind is identified as belonging also to the structure of Melanchthon's theology. In a paper delivered at the Congress on Calvin Research in 1974 I myself referred to the theology of Calvin as a "theology of the Word"36. If this is correct, then the newly discovered means of grace contained in the Word also determines the dogmatics of the authoritative Reformed theologian. We come to the conclusion that God's action through the sermon is a common evangelical discovery which is valid beyond the confessional frontiers of the 16th century. Therefore the question arises once more whether this basic unity between Luther and Calvin really does exist.

Previous research has grouped Calvin with Zwingli and Bucer. Scholars are of the opinion that Calvin follows the tradition of Zwingli and Bucer in separating Word and Spirit, that is, sermon and Holy Spirit, from each other. Human proclamation, however, is the necessary vehicle by which faith is known because the sacred activity of God in the Bible has to be proclaimed although the power to believe comes only through the Holy Spirit. One scholar ${ }^{37}$ has argued that in Calvin's thought "in actu alone God the Holy Spirit transmutes the oral Word into the 'Word of God' ..." If this were so,there would be no theological unity in Luther, because the emphasis on the preached Word is significant for the understanding of 
the Word of God in Luther and Melanchthon; they join the Holy Spirit to the Word ${ }^{38}$. Luther had reproved Zwingli and Bucer for the separation of the Word and the Spirit ${ }^{39}$.

Indeed a glance at Calvin's understanding of God indicates that the Genevan refomer, as far as the doctrine of the means of salvation is concerned, belongs on Luther's side. The biblical text which Zwingli cited most is John 6:46: "No one can come to me unless the Father who sent me draws him." The drawing is effected by the Holy Spirit. Zwingli's obvious strong liking for the visible means of salvation, Word and Sacrament, is rightly designated as spiritualistic. Bucer, too, despite changes in his theology, retained a spiritualistically based viewpoint ${ }^{40}$. In contrast to Zwingli Calvin, in the Institutes, describes God as the "God who speaks" (deus loquens)". He reveals Himself to mankind through the medium of the Word. In the Bible God revealed Himself through chosen witnesses, through patriarchs, priests, prophets, and in the New Testament through Christ and the Apostles ${ }^{42}$. Today God reveals Himself to men through the ministers of the Sacred Word. In his commentary on the 22nd Psalm (1530) Luther describes Christ as "King of the Word"43, that is, he rules his Church today through obedience to the Word of God. For Calvin and Luther God is the God who speaks.

But the fact remains that Calvin likes to put Word and Spirit side by side. How is this to be assessed? It is noticeable also that Calvin ascribes efficacy to the Word, where elsewhere he attributes such efficacy only to the Spirit. He can say for example: "The power of the Word of the Lord is great, ... so that what is hardest and stoniest is loosened when it comes into contact with the Word"44. When he mentions Word and Holy Spirit together it is always in such a way that both operate together. He asserts that God never separates His hand from His mouth ${ }^{45}$. The decisiveness with which Calvin projects this view leads to the conclusion that a basic unity exists between Luther and Calvin: both represent a theology of the Word. To express it somewhat differently, both agree in their teaching on the Word-Spirit-faith relationship. Nevertheless, a particular sentence from the Institutes III, 2, 33 is often quoted. It runs: "Without the illumination of the Holy Spirit, the Word can do nothing" (sine spiritus sancti illuminatione, verbo nihil agitur $)^{46}$. The sentence seems to contradict Calvin's utterance cited above, which speaks of the power of the Word. One scholar observes regarding the sentence that it proves the "powerlessness of the Word" in Calvin". Also W Krusche, who in his book Das Wirken des Heiligen Geistes nach Calvin thoroughly investigated the problem, was unable to classify the sentence properly. His conclusion in the light of Calvin's one statement runs: "Certainly Calvin often speaks as if the Word and the operation of the Spirit run parallel with one another; but it is never 
his view that the Word operates only externally and the Spirit internally"48. Again, "it would be hard to exaggerate the close intimacy which exists between the efficacy of the Word and the operation of the Spirit ${ }^{\prime 49}$. In contrast to Zwingli, Calvin teaches neither an operation of the Spirit before the proclamation, nor an external efficacy of the proclamation, to which the Spirit must first give power. Is this not what the sentence in the Institutes is saying, "Without the illumination of the Holy Spirit, the Word can do nothing"?

In the paper I delivered to the Congress on Calvin Research in 1974 I indicated that Calvin handles faith and certainty of faith separately. The certainty of faith is the higher stage of faith. In the famous chapter on faith in Institutes III, 2 Calvin discusses Word and faith first in paragraphs $1-6$, then in paragraphs 7 to 43 , Spirit and certainty of faith. Chapter 2 begins with the definition: "Faith is a firm and certain knowledge (firma certaque cognitio) of God's benevolence toward us, founded (fundata) upon the truth of the freely given promise in Christ, both revealed (revelatur) to our minds and sealed (obsignatur) upon our hearts through the Holy Spirit" ${ }^{\prime 50}$. In definition of faith Calvin first deals with certain knowledge (paragraphs 14-28), then its basis in the Word of promise (paragraphs 29-32), and finally its seal by the Holy Spirit (paragraphs 33-43). The noteworthy sentence, "without the illumination of the Holy Spirit, the Word can do nothing", belongs to the last paragraph which teaches the sealing of the Word of grace by the Spirit, that is, the certainty of faith. Word and Spirit stand together here. The emphasis is on the specific work of the Spirit.

Calvin's particular concern, however, is not mentioned. Only the elect of God receive the certainty of faith. God bestows on them the Spirit of assurance. "Only those predestined to salvation receive the light (illumanitio) of faith and truly feel the power of the gospel"51. Internal illumination and predestination belong together in Calvin. Whenever he came to speak of the small number of believers the subject of predestination is implied in his remarks. The conclusion suggests itself that Calvin and Luther both taught the Word-spiritfaith relationship, but Calvin also recognised a Word-Spirit-certainty of faith relationship, founded on predestination. The first stage (Word-Spirit-faith) advocates universal salvation, the second (Word-Spirit-certainty of faith) a limited salvation. Both lines of development are also found in Luther, "the emphasis on the sovereignty of the Spirit and the insufficiency of the external word on the one side and the emphasis on the rigorous adhesion of the Spirit to the Word on the other"52. This statement comes from R Prenter, who in his book Spiritus Creator. Studien zu Luthers Theologie describes this double line of thought as the "tension between a theology of predestination and reconciliation" ${ }^{\prime 23}$. 
We arrive at the conclusion that Luther expected the generation and strengthening of faith at each proclamation of the Word. Generally speaking he emphasised the unity of Word and Spirit more than Calvin. But there is also a motif of predestination in Luther. Clearly Calvin sought a systematic arrangement of both lines of development. It appears to me, however, at this point that the differences lie in nuance rather than dogma. Both advocate a theology of the Word.

A final statement ought not to occasion surprise after what has been said already. In the dispute over the bodily or spiritual presence of Christ in the Lord's Supper both reformers abandoned the Word-Spirit-faith line of development and took refuge in an ontological conception. Luther depended on the doctrine of consubstantiation and universality. Calvin on the dualism of res corporeae and res spirituales or signum and res signata ${ }^{54}$. But it is not expedient to use every weapon that can be taken up against the adversary.

\section{INTERNATIONAL STUDIES ON CALVIN AND LUTHER}

In conclusion, Luther and Calvin, have this in common: two international congresses have been occupied with them and their work. After the second world war Zwingli research, and even more research studies on Melanchthon, Bucer and Bullinger, made remarkable progress. It is surely no accident that the life and theology of Calvin and Luther became the object of more world-wide research and were undertaken with greater expectations than work on other reformers. The simple explanation could be given that Luther and Calvin were the outstanding figures among the reformers. But why are they outstanding?

With great caution I would suggest three reasons. First both were primarily expositors of the Bible. Throughout their lives they retained the faculty of steeping themselves in the Scriptures, constantly occupying themselves with the Word of God, constantly applying themselves to the exegesis of individual words in the biblical text. Their lively commentaries elevate them above their fellow reformers. Secondly, their literary powers of expression deserve mention. This applies just as much to their letters and sermons as to their major writings. One need think only of Luther's great reformation writings of the year 1520, the publication "On Temporal Authority" (1523) or the Schmalkalden Articles (1537). With Calvin his "Reply to Sadolet" (1539), the Introduction to the Institutes (1536) and the Institutes in their final form (1559) are preeminent. Even today one cannot miss the powerful language and ideas of these writings. Thirdly, their radiant effect on the community must be stressed. Certainly it was of a different kind with both men, but 
equally lasting. Luther's hymns, catechisms and his fearless appearance stand over against Calvin's requisition of the so-called laity to be leaders of the church in the presbytery, his church regulations and his self-denial in the service of Christ.

Certainly Luther was more popular than the sickly and controversial Calvin. Their names and their deeds are known as few other individual Christians. What struck me as the most surprising events at the International Congress on Calvin Research, which met in Amsterdam from 25 to 28 September 1978, was that representatives from Huhgary, South Korea and South Africa expressed the wish to hold regional congresses in their countries. It is obvious that they not only give promise of scholarly progress, but also provide help for their particular ecclesiastical problems. The International Congress on Calvin Research is not as old as the World Congress on Luther Research. An important difference appears to me to be that Luther scholars endeavour at their Congress to arrive at an approximation of viewpoints in regard to specific questions which entail divergent results. The Calvin scholar tries to fill in the lacunae in scholarly studies and to coordinate Calvin research. The structure of Calvin's theology is still a mystery, which prevents us for example from giving a summary of the theology which is expressed not only in the Institutes. The dependence of Calvin on the church fathers and the late medieval Schoolmen has received too little attention. An urgent task is the investigation of Martin Bucer's influence on Calvin. Added to this is the wide field of Calvin's commentaries and sermons. We hope that the Congresses - the next International Congress is due to take place in Geneva in 1982 - bring fresh results and incentives for scholarly study.

\section{Footnotes}

1. This material with references is set forth conveniently in August Lang, "Luther und Calvin", in Reformation und Gegenwart, Detmold 1918, pp $72 \mathrm{ff}$.

2. Cf Lang, Die Quellen der Institutio von 1536, Evangelische Theologie 3, 1936, pp 100 ff.

3. J Rott, Documents strasbourgeois concernant Calvin, Revue d'histoire et de philosophie religieuses 44,1964 , pp 325-331.

4. I have already treated this in "Calvins Beitrag $z u$ den Religionsgesprächen von Hagenau, Worms und Regensburg (1540/41)", Festschrift for Ernst Bizer, edited by L Abramowski, JF Goeters, Neukirchen 1969, pp $213 \mathrm{ff}$; also found in "Calvin", Sammlung Göschen Nr 3005, Berlin 1971, pp $48 f$.

5. Calvini Opera (hereafter CO) 10b, 402.

6. M Simon, Um Gottes Ehre! Vier kleine Schriften Calvins, München 1924; G Gloede, MuBte Reformation sein? Calvins Antwort an Kardinal Sadolet, Göttingen 1954.

7. $\mathrm{CO} 10 \mathrm{~b}, 432$.

8. Found in Opera Selecta (hereafter OS), 1,472.

9. This view is found in OS $1,352,36$. 
10. The beginning is missing. Text: OS $5,353,19-45$ and $354,30-355,36$. Also Herminjard, Correspondance des Reformateurs, 6, 132-137.

11. Calvin to Farel, January 10, 1540; Herminjard, 6,165.

12. Iuxta verbi Irenaei constare Eucharistiam duabus rebus, terrena et coelesti (Wittenberger Konkordie, CR Melanchthon 3,75) - Dico igitur (quod et semper in Ecclesia receptum fuit, et hodie docent quicunque recte sentiunt) duabus rebes constare sacrum Coenae mysterium (Institutes of the Christian Religion (hereafter Inst.) IV, 17, 11; OS 5,352,23).

13. OS 5,354,35-37 $=1,136,37-39$ (Inst. 1536 and 1539).

14. OS $5,355,4-8$.

15. Inst IV, 17,12; OS $5,355,8$.

16. So Herminjard 6,133 , note $61 / 62$, OS 5,355 , note 2 .

17. J Rott, op cit p 328.

18. J Rott, op cit $\mathrm{p} 328$.

19. J Rott, op cit p 330.

20 CF Calvin's letter of April 1539 to A Zébédée, CO 10b, No 171.

21. Cf WH Neuser, Calvins Beitrag, pp 213f. B Klaus, Veit Dietrich, Leben und Werk, Nürnberg 195B, pp 321ff.

22. Inst III, 7, 9 and CO 55,314, cf Werner Krusche, Das Wirken des Heiligen Geistes bei Calvin, Göttingen 1957, pp 281ff.

23. J Ficker, Luthers Vorlesung über den Römerbrief, RS 267,7 (RS $=$ Scholien), cf Wilhelm Link, Das Ringen Luthers um die Freiheit der Theologie von der Philosophie, München $1955^{2}$, pp 77ff. Wilhelm Joest, Paulus und das Lutherische simul iustus et peccator, Kerygma und Dogma 1, 1955, pp 269ff; H Schütte, Protestantismus, Essen-Werden 1966, pp 341-347, 409-430.

24. Die christliche Lehre nach dem Heidelberger Katechismus, München 1949, p 21.

25. Weimarer Ausgabe (hereafter WA) 39, I pp $198 \mathrm{ff}$.

26. L Pinomaa, Die profectio bei Luther, in the Festschrift for D Werner Elert, Berlin 1955, pp 119ff: “Man kann nicht gleichzeitig 'simul iustus et peccator' und profectio lehren" ( $p$ 119).

27. Grundlagen der Dogmatik, Bd 2, Neukirchen 1962, p 358.

28. Luther was not an antinomian as the Antinomian debates of 1527 and later show. J Agricola and the other "Antinomians" were mystics who completely set aside the law of God. See Weber, op cit p 359, note 1.

29. Calvin et l'humanisme, Cahiers de la Revue d'histoire et de philosopie religieuses No 45, Paris 1976, p 8.

30. Op cit Bd 2, pp 414f.

31. To be sure Pocque and Quintin are not meant here, against whom he aims in his tract "Contre la secte fantastique des Libertins" (1545).

32. Op cit Bd 2, $\mathrm{p} 415$.

33. Inst II.7.12.

34. For example, Religion in Geschichte und Gegenwart, 3rd edition, Vol I, p 1144. From the Catholic side see $\mathrm{H}$ Schüte, op cit $\mathrm{p} 480$.

35. Studien zur Theologie des jungen Melanchthon 1519-1524, Neukirchen 1964.

36. Calvinus Theologus. Die Referate des Europäischen Kongresses für Calvinforschung, edited by WH Neuser, Neukirchen 1976, pp 17ff.

37. $\mathrm{OH}$ Nebe. See Krusche, op cit $\mathrm{p} 226$.

38. E Bizer, Theologie der VerheiBung, $\mathrm{p} 217$.

39. Cf W Köhler, Zwingli und Luther, Bd 2, pp 78f, and the Marburg Articles, No 8.

40. E Bizer, Studien zur Geschichte des Abendmahlsstreits im 16. Jahrhundert, Darmstadt $1962, \mathrm{p} 125$.

41. Inst I.7.4; OS $3,68,30$.

42. CF WH Neuser, Theologie des Wortes, op cit pp $21 \mathrm{f}$.

43. Erlanger Ausgabe 38,231; WA 31 I,362,2 (rex verbalis).

44. $\mathrm{CO} 5,281$.

45. $\operatorname{CO} 41,112 ; 40,272$.

46. OS IV 44,9 .

47. $\mathrm{OH}$ Nebe, cf Krusche, op cit $\mathrm{p} 224$.

48. Pp 228f. 
49. P 231.

50. Inst III, 2,7; OS IV, 16,31 .

51. Inst III,2,11; OS IV,20,28.

52. Cf Krusche, op cit $\mathrm{p} 228$, note 553.

53. $P 111$.

54. Inst IV,15,14; OS 5,295,17. Inst IV,17,21; OS 5,370,8.19. 